\title{
Essential Oils in Treatment and Management of Dental Diseases
}

\author{
Inderbir Singh ${ }^{1, *} \mathbb{D}$, Parneet Kaur ${ }^{1 \mathbb{D}}$, Udesh Kaushal ${ }^{1 \mathbb{D}}$, Vimanpreet Kaur ${ }^{1 \mathbb{D}}$, Navendu Shekhar ${ }^{1}$ \\ 1 Chitkara College of Pharmacy, Chitkara University, Rajpura-140401, Patiala, Punjab, India; \\ inderbir.singh@ chitkara.edu.in (I.S.); \\ * Correspondence: inderbir.singh@ chitkara.edu.in (I.S.);
}

Received: 20.09.2021; Revised: 20.10.2021; Accepted: 24.10.2021; Published: 24.11.2021

\begin{abstract}
Essential oils have considerable potential as a preventive and therapeutic agent against various oral diseases and, in particular dental diseases. Wider potential of essential oils as an antimicrobial and anti-inflammatory agent is mainly responsible for their use in dental diseases. In the present review article, commonly used essential oils in dentistry have been explained systematically. The therapeutic efficacies of different essential oils in different dental diseases, viz. periodontitis, dental erosion, dental caries, dental pain, gingivitis, and plaque, have been discussed extensively. Finally, patents filed by various innovators on essential oils-based formulations and their applications in dental care have been well tabulated. In conclusion, essential oils have significant the potential for the management and treatment of various dental diseases. However, various preclinical and clinical studies supporting the safety and efficacy of essential oils must be performed for regulatory compliance and commercial exploitation of essential oil-based formulations.
\end{abstract}

Keywords: essential oil; antimicrobial; anti-inflammatory; dental diseases.

(C) 2021 by the authors. This article is an open-access article distributed under the terms and conditions of the Creative Commons Attribution (CC BY) license (https://creativecommons.org/licenses/by/4.0/).

\section{Introduction}

Essential oils include volatile aromatic solvents synthesized by delicate frameworks in plant parts such as leaves, fruits, seeds, resins, woods, barks, and berries. The term "essential" was given to these oils since they were assumed to trap the essence of a plant, that is, its taste and odor. They offer their distinctive scent to plants. Essential oils are raw, intensely reactive, condensed, water-insoluble fluids found in various plant parts. These are also known as aetherolea, ethereal oils, or volatile oils. They seem to be less viscous than oil, despite the word "oil,"and have more of a watery appearance [1].

Essential oils consist of a diverse combination of elements, often comprising thousands of essential oils. The unique percentage of all the ingredients yields the oil its special wellbeing and medicinal properties. Frequently known group of essential oil components including monoterpenes, diterpenes, sesquiterpenes, aldehydes, ketones, esters, alcohols, phenols, and oxides because of the health-boosting and purifying qualities which separate several elements, certain essential oils are antiseptic, and some of whom have anti-fungal, antibacterial, and antiviral properties $[2,3]$.

The presence of the essential oils varies from either colorless to further some color of the spectrum, and most of the color of the oil relates to its medicinal properties. For example, being blue, Chamomile Oil is generally useful for the aromatherapy massage undergoing "red hot" emotions since blue reflects its typical "cooling and soothing" action and stimulates both 
physical and emotional feelings. Oils like Patchouli, Citrus, and Lemongrass are yellow or amber. Their vibrant, cheerful colors will quickly help individuals decide that these are often considered a potential mood enhancer. Fairly young plants produce a greater number of essential oils than mature plants, but because of the constant evaporation of the lighter fractions of the oil, the latter creates oils that are far more resinous and dark in color. Often their colors are the outcome of the extraction process, and the color of the plant part influences the color of the finished material. Although Chamomile is not blue, it produces an ingredient named Chamazulene, that during the distillation process, it transforms the oil to an inky blue color [4].

One of two methods, namely extraction or distillation, is used to manufacture the essential oils, and it tends to depend on the source from which it is extracted. All essential oils are obtained from a plant source - whether it be from the bark, fruit, leaf, flower, or root. To extract a relatively small quantity of essential oil, the technique of refining pure essential oils also takes many pounds from the plant's natural source. The pure therapeutic-quality oils produced, in general, are often expensive. The bulk of pure essential oils are so intense that they have to be processed for effective use.

The first technique is a topical treatment, i.e., applying essential oils on the body's nails, skin, teeth, mouth, hair, or mucous membranes. This requires direct implementation, massage, hot compresses, and the incorporation of oils into bathwater. The process of oil pulling is one method of topical application; oils are scooted for 5-20 minutes in the mouth. When essential oils are introduced into the methods of oil-pulling, they are applied to some other oil, such as olive oil or coconut [5].

The next technique is the scented process, which includes fine oil mist or a cloud of volatile aromatic compounds vaporized from the oil is inhaled. Aromatherapy, by the olfactory system, regulates memory, nerves, and feelings. By diffusion, direct inhalation, hot water vapor, jets, windows, humidifiers, perfumes, or hair gel, essential oils may be used in aromatic form [6]. The final application process is subjective; the oil is absorbed or otherwise internalized into the body. The internal use of essential oils involves the incorporation of oils underneath the tongue, the addition of oils to liquids or foods during preparation, and the placement of oil-filled capsules for consumption. They recognize that for internal usage, only pure oils can be utilized. Most essential oils are classified as GRAS by the US FDA, which means they are widely accepted as suitable for human utilization.

Fortune business insight "Essential oil market size, growth and share"' The worldwide consumer demand for essential oils was projected at 247.08 kilotons in 2020 and is projected to rise from 2020 to 2027 at a compound annual growth rate (CAGR) of 7.5 percent. Rising demand from large end-use sectors, such as food and drink, personal care and cosmetics, oral care, and aromatherapy, is expected to boost the market. The food and beverage industry is the major supplier of essential oils serving as natural antimicrobials. Many beneficial effects related to essential oils are expected to boost their market in medicinal and therapeutic uses. Essential oils have no significant adverse effects, despite other traditional medications and products [7].

The efficacy of several essential oils has been studied extensively for oral hygiene. Spearmint oil is the most widely used essential oil in oral care treatments. Lavender oil also contributes to oral diseases, followed by cinnamon oil. Coconut oil and Eucalyptus oil are also used for this purpose. Lemon, Clove, and tea tree oils are less widely used as compared to others. 


\subsection{Potential applications of essential oils.}

Anxiolytic/Relieves anxiety-The fragrance of basic lavender oils can adjust mental states and alleviate moderate anxiety. When used in waiting rooms, it has been reported to help decrease anxiety and stress in dental patients [8]. It also decreases needle injection pain. Aromatherapy with natural orange essential oil has been shown to help reduce salivary cortisol hormone and pulse rate caused by childhood stress [9].

Oral hygiene-In inhibiting plaque, essential oil rinses have been found to be equally effective. Essential oil rinses are found to be equally efficient. As chlorhexidine induces longterm staining of the teeth, essential oils are used as an alternative to rinsing with chlorhexidine [10]. Subgingival peri pathogens have often been found to exhibit antimicrobial activity against essential oils [11]. Even so, a review carried out with and without ethanol on the effectiveness of essential oils found that essential oils only aren't that beneficial.

In dental implants-It has therefore been observed that certain essential oils exhibit antibiofilm efficacy. It's possible to use them for dental implants. The use of essential oils on dental implant surfaces has been found to prevent the development of biofilms [12].

Wound dressing is possible to derive stronger healing results from wound dressings containing essential oils. Hence, during oral surgical operations, they may be used to achieve faster recovery. This can improve therapeutic effects and healing time [13].

As preservative-Essential oils demonstrated greater inhibitory activity than extracts and methyl paraben against the measured microorganism strain. Essential oils are used to replace methyl paraben in cosmetic emulsions, often used as a preservative in different dental products, specifically in patients who are allergic to methyl paraben [14]. It could be used in LA allergy, although this involves more clinical testing to evaluate its usefulness as a preservative and whether or not it can be administered into the human body; as far as the best of our understanding is concerned, no experiments have been carried out so far in which essential oils are administered into the human body.

\section{Commonly Used Essential Oils in Dentistry}

\subsection{Clove oil.}

Clove oil is an essential oil obtained from the leaves of clove trees (Family: Myrtaceae). The primary constituents of the essential oil are phenylpropanoids such as eugenol, carvacrol, thymol, and cinnamaldehyde. Clove oil can be used to improve tooth pain and poor breath, help prevent gum disease, and even found used in the fragrance and flavoring industries. Clove oil also has the innate potential to limit the growth of bacteria and can help control diseases of the mouth and throat [15].

\subsection{Lavender oil.}

Lavender oil can be obtained by steam distillation through the flowers of Lavandula angustifolia (Family: Lamiaceae) by steam distillation $[8,16]$. The key constituents of lavender are camphor, linalyl acetate, terpinen-4-ol, 1,8-cineole B-ocimene, and linalool. In dental hospitals, it can be used to reduce the pain and suffering of patients. When used in hospital waiting rooms, it is considered effective as an anxiolytic tool and can be used as well for periodontal medical treatments [9]. 


\subsection{Cinnamon oil.}

Cinnamon oil is obtained either from the bark or leaves of different trees, such as the Cinnamomum verum tree and the Cinnamomum cassia tree (Family: Lauraceae). The main components are caryophyllene, cinnamaldehyde, eugenol, camphor, cinnamyl acetate, and linalool. Cinnamon is antibacterial, antiseptic, and anti-fungal, making it an important cleanser for the need for oral health treatment, such as calming a sore throat. One of the greatest antimicrobial properties is protection against bacteria which is responsible for tooth decay is also found in cinnamon oil [17].

\subsection{Eucalyptus oil.}

Eucalyptus globulus (Family: Myrtaceae), also called Blue Gum, is the main source of eucalyptus oil. The primary constituents are $\alpha$-pinene, 1,8-cineole, cryptone, $\alpha$-terpineol, transpinocarveol, globulol, terpinene-4-ol, cuminal, limonene, and aromadendrene. Eucalyptus oil has a potent cytotoxic and antibacterial activity against Staphylococcus pneumonia, Staphylococcus aureus, Haemophilus influenzae, Staphylococcus pyogenes[18]. Essential oil can activate the immune response affected by the innate cell, triggering its use as an adjuvant in infectious disease, immunosuppression, and tumor chemotherapy [19].

\subsection{Lemon oil.}

The lemon essential oil is derived from the Rutaceae family of Citrus limonum (also known as Citrus Limon). Lemon oil contains aldehydes, terpenes, esters, and sesquiterpenes. By killing bacteria, lemon oil help to avoid dental cavity and receding gums. Other characteristics of lemon oil are believed to promote the growth of tissue and can encourage healthier gums. It serves as a natural treatment for many oral disorders, such as oral thrush and bad breath, because lemon essential oil has antibacterial and anti-fungal properties. It could also be used to naturally whiten the teeth and avoid dental decay [20].

\subsection{Tea tree oil.}

Tea tree oil arises from the Melaleuca alternifolia leaves (Family: Myrtaceae). Tea tree oil contains $\alpha$-terpinene, terpinen-4-ol, terpinolene, $\gamma$-terpinene, $\alpha$-pinene, and p-cymene. Due to its ability to kill off bacteria, decrease tooth decay and alleviate bleeding gums, this oil is an ideal component for a DIY toothpaste or mouthwash. In treating herpes simplex virus, aphthous ulcers, dental pain, periodontitis, refractory oral candida infections, and herpes simplex virus, tea tree oil is useful. In toothpaste, mouth rinses, toothpicks, coated floss, and gels, Tea Tree Oil can be included [21].

\subsection{Ylang-ylang oil.}

Ylang-ylang oil is extracted from freshly harvested flowers of Cananga odorata tree (Family: Annonaceae). The key constituents of ylang-ylang oil are benzyl benzoate, methyl benzoate, geranyl acetate, geraniol, benzyl acetate, cinnamyl acetate, and linalool. Inhibiting biofilm, Ylang-ylang destroys bacteria and has anti-inflammatory effects. While ylang-ylang is possibly known to be widely used in cosmetics or aromatherapy, research reveals that it has a multitude of beneficial substances [22]. 


\subsection{Coconut oil.}

Coconut oil is manufactured by crushing dried coconut meat or fresh coconut meat called copra (Family: Arecaceae). Coconut oil is comprised of oleic acid, fatty acids, capric acid, palmitic acid, caprylic acid, lauric acid, stearic acid, myristic acid, and linoleic acid. Coconut oil is effective in avoiding cavities and gum disease. It removes and even decreases plaque adherence and build-up. It has some antimicrobial effects that can help keep gums clean, keeping them productive towards cavity-causing bacteria, a significant health benefit for those with dry mouth [23].

\subsection{Spearmint oil.}

Spearmint Oil is separated by the bright green Mentha spicata herb (Family: Lamiaceae). The primary constituents are carvyl acetate, carvone, 1,8 cineol, cis-carveol, cissabinene hydrate limonene, and cis-dihydrocarvone. Because of its good, minty flavor and potential to encourage fresh breath, spearmint is being commonly used for sweets, gums, and oral hygiene products. Spearmint oil is a moderately severe substitute to some of the more strong mint oils, but it also supplies the mouth with effective soothing and relaxing properties [24]. Table 1 lists various essential oil constituents, along with their botanical names and plant parts used.

Table 1. Plant source, constituents, and uses of essential oils in dentistry.

\begin{tabular}{|c|c|c|c|c|}
\hline S. No. & Essential Oil & Plant Source & Constituents & Uses in dentistry \\
\hline 1 & Clove oil & $\begin{array}{l}\text { Eugenia caryophyllata } \\
\text { Part -Leaves }\end{array}$ & $\begin{array}{l}\text { Eugenol, carvacrol, eugenyl acetate, } \\
\text { thymol, cinnamaldehyde, } \\
\text { caryophyllene, and 2-heptanone. }\end{array}$ & $\begin{array}{l}\text { To treat toothaches, clove oil has } \\
\text { long been added directly to the } \\
\text { gums. }\end{array}$ \\
\hline 2 & Lavender oil & $\begin{array}{l}\text { Lavandula angustifolia } \\
\text { Part -Flower spikes }\end{array}$ & $\begin{array}{l}\text { Linalool, linalyl acetate, } 1,8 \text {-cineole, B- } \\
\text { ocimene, terpinen-4-ol, l-fenchone, } \\
\text { viridiflorol, and camphor. }\end{array}$ & $\begin{array}{l}\text { Used to reduce bacteria, relieve } \\
\text { pain, soothe inflammation. }\end{array}$ \\
\hline 3 & Cinnamon oil & $\begin{array}{l}\text { Cinnamomum verum } \\
\text { Part - Bark or leaves of } \\
\text { Cinnamomum verum tree } \\
\text { and the Cinnamomum } \\
\text { cassia. }\end{array}$ & $\begin{array}{l}\text { Trans-cinnamaldehyde, eugenol, and } \\
\text { linalool }\end{array}$ & $\begin{array}{l}\text { In treating oral candidiasis. Used } \\
\text { against the action of oral } \\
\text { pathogens involved in dental } \\
\text { carries. }\end{array}$ \\
\hline 4 & Eucalyptus oil & $\begin{array}{l}\text { Eucalyptus citriodora } \\
\text { Part - Dried eucalyptus } \\
\text { leaf }\end{array}$ & $\begin{array}{l}\text { 1,8-cineole, cryptone, } \alpha \text {-pinene, p- } \\
\text { cymene, } \alpha \text {-terpineol, trans-pinocarveol, } \\
\text { phellandral, cuminal, globulol, } \\
\text { limonene, aromadendrene, spathulenol, } \\
\text { and terpinene-4-ol. }\end{array}$ & $\begin{array}{l}\text { Control of gum disease as an anti- } \\
\text { plaque component for gum } \\
\text { bleeding. }\end{array}$ \\
\hline 5 & Lemon oil & $\begin{array}{l}\text { Citrus limon } \\
\text { Part -Lemon grass oil }\end{array}$ & Terpenes, d-limonene and 1-limonene & $\begin{array}{l}\text { Lemon oil can help prevent } \\
\text { receding gums and tooth decay } \\
\text { by fighting against bacteria. }\end{array}$ \\
\hline 6 & Tea tree oil & $\begin{array}{l}\text { Melaleuca alternifolia } \\
\text { Part -Leaves }\end{array}$ & $\begin{array}{l}\text { Terpinen-4-ol, } \gamma \text {-terpinene, } \\
\text { p-cymene, } \alpha \text {-terpinene, } 1,8 \text {-cineole, } \alpha \text { - } \\
\text { terpineol, } \\
\text { and } \alpha \text {-pinene. }\end{array}$ & $\begin{array}{l}\text { Appropriate for use in oral } \\
\text { hygiene and oral candidiasis } \\
\text { prophylactic drugs }\end{array}$ \\
\hline 7 & Ylang-Ylang & $\begin{array}{l}\text { Cananga odorata Hook. } \\
\text { F. \& Thomson } \\
\text { Part -Flowers }\end{array}$ & $\begin{array}{l}\text { Geranyl acetate, linalol, geraniol, } \\
\text { farnesol, benzyl acetate, geranial, } \\
\text { methyl chavicol, beta-caryophyllene, } \\
\text { eugenol, pinene. }\end{array}$ & Useful in periodontal disease \\
\hline 8 & Coconut oil & $\begin{array}{l}\text { Cocos Nucifera } \\
\text { Part - coconut meat }\end{array}$ & $\begin{array}{l}\text { Fatty acids, caprylic acid, capric acid, } \\
\text { lauric acid, myristic acid, palmitic acid, } \\
\text { stearic acid, oleic acid and linoleic acid. }\end{array}$ & $\begin{array}{l}\text { It can decrease plaque build-up, } \\
\text { avoid tooth loss and prevent gum } \\
\text { disease. }\end{array}$ \\
\hline 9 & Spearmint oil & $\begin{array}{l}\text { Mentha Viridis } \\
\text { Part ᄀ-Leaves }\end{array}$ & $\begin{array}{l}\text { Carvone, cis-carveol limonene, } 1,8 \\
\text { cineol, cis-dihydrocarvone, carvyl } \\
\text { acetate, and cis-sabinene hydrate. }\end{array}$ & It can help soothe toothaches \\
\hline
\end{tabular}




\section{Introduction to Oral Health}

Such decent oral hygiene wasn't ever practiced by individuals. 87percent of people seem to retain a little natural tooth, yet only a 13 percent of the total individuals have lost all remaining teeth. A good mouth does make a significant contribution to the standard of life of an individual. Individual who are not capable to manage their oral health and may consult to the physician. Mouth care is a major measure of the level of care received by a patient. Bad dental hygiene can lead to severe health complications like pneumonia in vulnerable aged people $[25,26]$. There is a higher chance of tooth decay in people who have poor oral hygiene [27].

\subsection{Oral cavity.}

The lips, laterally by the fauces, laterally by the cheeks, superiorly by the palate, and inferiorly by the muscular floor, form the oral cavity or mouth, which is the first component of the digestive tract. The tongue occupies the available space in the arch of the lower teeth on the floor of the mouth. It is possible to split the oral cavity into 2 parts: (1) Vestibule, which is the space between lips or cheeks and the teeth; (2) Oral cavity, which is the region between the teeth and the lips or cheeks. The oral cavity is lined with a moist stratified epithelium that varies in appearance depending on the location. The oropharynx is the part just below the mouth of the throat. It comprises the tongue base, the soft palate, the tonsils, and the throat side and back wall [28].

The oral mucosal is lined with a mucous layer with an epithelial layer and hence interconnected tissue underneath it. Protection, taste perception, and biting are only a few roles of the ocular surface. The coating of the mucosal surface must be as resilient as possible to be beneficial. To survive adequate feed crushing, it has a highly vascularized epithelium coating and connective tissues closely bound to the surface [29].

\subsection{Teeth.}

The teeth are comprised of superficially mineralized, inactive, even acellular fibers (enamel, an absolute strong tissue extracted by ectodermal epithelial recognized as ameloblasts). However, this one is also accompanied by lesser mineralized, quite reliable. Yet, necessary strong tissue, through the rich vascularized as well as vascular elastic fibers had been constructed or even maintained.

Anatomically, a tooth is made up of a crown or even a base, and also the cervical edge seems to be the point where the two meet. Teeth play an integral character in nutrition production due to the different actions done by their enamel surface throughout chewing. Further, the teeth's potential is determined through the abundant hydrated biological apatite crystals mostly in organic substance, the proportion of teeth, the whole basal area, structured from occlusal layers, even the accompanying structures [30,31].

A basic examination throughout the humanoid tooth's exterior anatomy exposes 3 distinguishing sections: The crown seems to be the component in the teeth coated by enamel material on the outside. Whenever anybody smiles, it is usually one other aspect visible, but the gums may obscure a minor amount of it. Each role of the teeth is affected by the characteristics, including its crown. For mostly carving, only the incisors and canines are extremely strong or even chisel-shaped, while primary teeth and incisors include 2 or 3 cusps. 
The gumline is the border region of the teeth among each peak, and even the base is recognized as the gumline. Because of the color contrast amongst pigment $\&$ cementum, such a pattern is apparent only visually. The root of a teeth seems to be the segment within the teeth that was lodged inside the joint; it contributes nearly two-thirds of its tooth's total composition and is coated by cementum.

\subsection{Gums.}

This is what dentists call gingiva. It protects the teeth covering the bone. Such tissues are maintained preserved by cleaning teeth following meals as well as flossing every day. That is significant, although bone deterioration can be caused by gum disease. The tooth root may also become vulnerable to rotting through gum disease. Whenever root degradation affects the pulp, a specialized fitting labeled a root filling may also be required for the patient.

\subsection{Salivary glands.}

Three paired collections of the main salivary gland and around 1,000 small glands distributed across the buccal cavity, including the oropharynx, produce saliva, which maintains the mouth hydrated and helps with mastication, chewing, and absorption [32,33]. The small salivary glands often exist in the mouth tongues, mucous membrane, and palette, and they're often situated in sinuses, supraglottis, and laryngeal cavities. Each minimal salivary gland has a standard duct that absorbs serous, mucosal, combined saliva effectively further into the oral compartment [34,35].

Mastication muscles are elongated muscles that assist through munching, grinding jaws, moving the mandible across different directions, offering the throat, including talking. Both muscle fibers operate in tandem through a working muscle for munching, throat shifting, face displacement from sideways, including bottom jaw displacement [36,37].

\section{Dental Diseases}

According to the World Health Survey [World Health Survey 2003 India] conducted in India in 2003 by the World Health Organisation (WHO), 28 percent of respondents had an oral health problem, with a maximum of 42 percent coming from West Bengal. The survey published by Khan et al., 2008 indicates that the rate of dental caries is as significant as 60-65 percent in some parts of the world, while the relative risk is 35 percent globally [38].To assess the health condition and proliferation of dental diseases in relevant age groups, a systematic and comprehensive national health investigation was carried in India in 2004 [39,40]. Overall severity of dental caries (coronal and root surfaces) for different age groups, regional distribution. Various types of dental diseases are there, as shown in Figure 1.

To avoid tooth decay and gum infections, oral health is a process of maintaining the teeth clean, safe by brushing and flossing. Oral hygiene can even be regarded as the overall cleanliness of the mouth, and to keep it hygienic, there are effective cleaning tools. Oral hygiene aims to keep teeth free of plaque-related issues, including gum infections and tooth loss (a major cause of cavities). Plaque is the sticky substance that forms on the teeth many hours after eating and is mainly bacteria that has not been washed away. When bacteria expand, they generate acid that eats through the tooth's enamel, permitting the typical cavity to build. As the tooth is eroded by more acids, it becomes unbearable. As plaque sticks to the crevices and fissures of the teeth, it destroys the protective enamel surface of the teeth when it is not 
regularly cleaned, causing the development of cavities (holes). Gum disorders known as periodontal disease and tooth decay can also contribute to plaque. It's called tartar, as plaque is deposited on the tooth [41].

Diseases are any deviation from or disruption of any aspect of the body's natural configuration and operation. In most cases, antilogy, pathology, and prognosis are understood because oral relates to the mouth, so oral diseases are disturbances involving the oral cavity of human beings caused by inadequate oral hygiene. It is expressed by a distinctive collection of clinical symptoms. Oral floss is the invasion of the oral cavity by pathogens that are nonpathogenic in most situations but that can become pathogenic in specific circumstances. In the oral cavity, various microorganisms are present, but only several microbes can be known as real oral pathogens or odontopathogens. The most common bacterial infection in humans is caused by these odontopathogens: plaque, tartar, gingivitis, periodontitis, tooth decay [42].

Both caries and gingivitis begin in childhood, but caries become more active during puberty as the teeth become more fragile, and the process is accelerated by sweets or the use of syrup-soaked conformers. It is very difficult to handle caries and their variants or, ideally, to eliminate them from the vast majority of dentistry for infants. Gingivitis is reversible at this stage or fully preventable if the teeth are effectively cleaned. The prerequisite for orthodontic therapy is to deal with both conditions in many infants. Teeth abnormalities will produce extra areas of stagnation and make it more difficult to manage plaque. Early tooth loss (usually due to decay) would necessitate orthodontic treatment for the permanent successors to erupt into the arch. Orthodontic instruments, on the other hand, promote stagnation, making plaque control more difficult.

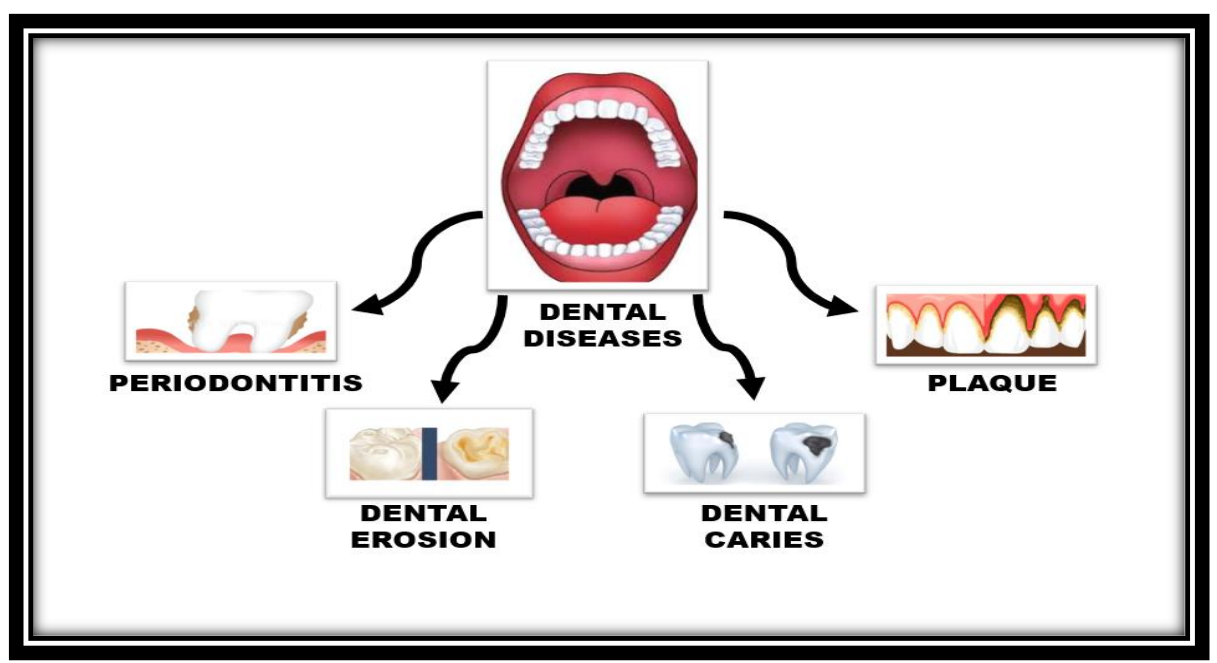

Figure 1. Commonly existing dental diseases.

\subsection{Tooth decay (dental caries).}

Tooth deterioration is most typically known as tooth decay. This stems from such a significant interaction amongst the pathogenic microorganisms, the material of the teeth, as well as the beverages contaminants. The specific causes are still unproven, but perhaps the acidogenic hypothesis is widely understood in the etiology of dental decay. This indicates that somehow oral microbiota (such as streptococci, lactobacilli, and actinomycetes) create acids in drinks and snacks from processed carbohydrates. Therefore, the acids strike the tooth surface, adding to decay. 
Dental caries is the most common and long-lasting oral disease, particularly in children $[13,43]$. Dental caries with a multifactorial etiology is a progressive infectious process. Dietary patterns, oral toxins that ferment sugars, and host susceptibility must all coexist for dental caries to begin and spread. It was, thus, the primary priority of the practitioners in dental health. Dental caries are induced by the dental plaques on the tooth surface [44,- 45]. It causes discomfort in the mouth, inflammation, poor chewing, weakening of tooth and impaired learning of language. WHO concluded that impaired oral health can have a tremendous influence on overall life quality and that chronic diseases are associated with many oral diseases. Dental caries relates mostly to localized degradation by acidified metabolic end of the microbial digestion of nutritional carbs of prone dental hard tissues. It is a chronic condition that develops steadily in several individuals, arising with an environmental difference in the equilibration of tooth nutrients and oral biofilm formation (plaque). The biofilm is characterized by bacterial growth leading to plaque $\mathrm{pH}$ variation. This is a function of either the producing bacteria acid and the stabilizing effect of saliva or the composition of the underlying tooth [46-47].

Bochra Kouidhi et al. stated that oral microorganisms, mainly cariogenic bacteria, are responsible for dental caries. In reference to the study conducted, it was found that the essential oil Eugenia caryophyllata (Clove) was investigated in vitro among a significant range of oral pathogenic organisms (46 strains of yeast and 114 streptococci) utilizing the process of disc diffusion [48]. Anand et al. studied the oil-pulling effect and was concluded that there was a considerable decrease in the total bacterial count. The oil-pulling process reduced the sensitivity of a host to dental caries. During 40 days of oil-pulling, the rate of decrease in the gross bacterial count reached 20 percent. Furthermore, in suppressing the growth of bacteria and adhesion, sesame oil is proven to be successful [49]. Aneja et al. described that acetone cinnamon concentrate risen as an effective agent showing far greater anti-fungal activity than the typical anti-fungal drug amphotericin-B. Most phytochemical analysis studies could open up the possibility of discovering new biologically beneficial bacteriostatic and bactericidal compounds against dental caries pathogenic organisms and sensitive bacterial and fungal strains; the need of the hour is to conduct ever more testing of natural products or plant sections [50]. Parisa Moghadam et al., Considered the detection of organic antibacterial compounds \&medicinal plants. One of Iran's indigenous trees, the Sumac (Rhus coriaria), is being utilized as a flavor enhancer. This was reported that Sumac essential oil has an adequate antimicrobial property that could be employed in the pharma companies against oral bacterial infections and dental caries to develop antimicrobial drugs and mouthwash [51]. Shetty et al. reported the extracts of Citrus sinensispeels to be good against microbes of dental caries and include potential beneficial substances. However, before promoting large treatment, clinical research on the effects of such plants are necessary [52] — application of essential oil in the management of dental caries in Table 2.

Table 2. Application of essential oil in the management of dental caries.

\begin{tabular}{c|l|} 
S. No. & Title \\
\hline 1 & $\begin{array}{l}\text { Anticariogenic and cytotoxic activity of clove } \\
\text { essential oil (Eugenia caryophyllata) }\end{array}$ \\
\hline 2 & $\begin{array}{l}\text { Effect of oil-pulling on dental caries causing } \\
\text { bacteria. }\end{array}$ \\
\hline 3 & $\begin{array}{l}\text { Antimicrobial activity of Dalchini } \\
\text { (Cinnamomum zeylanicum bark) extracts. }\end{array}$ \\
\hline 4 & $\begin{array}{l}\text { Antibacterial Activities of Sumac Fruit (Rhus } \\
\text { coriaria) Essential Oil }\end{array}$
\end{tabular}

Eugenia caryophyllata was found to be effective, anti-fungal as well as antibacterial action against oral streptococci and cariogenic bacteria.

Oil-pulling effect of sesame oil was studied. It was concluded that sesame oil acts as antibacterial against $S$. mutans. It also possesses antiadhesion properties. acetone extract was considered to be potent anti-fungal against oral pathogens. 


\subsection{Periodontal diseases.}

Periodontal disorder is a progressive disease that is only noticeable in midlife. There is no proof of a link between diet and periodontal disease, in addition to extreme vitamin $\mathrm{C}$ deficiency, which contributes to scurvy-related periodontitis, while current attention focuses on the possible preventive function of oxidative compounds. The existence of plaque seems to be the major important aspect in the etiology of periodontal disease, and preventive efforts are based on dental hygiene. There must be some confirmation that periodontal disease occurs more quickly in malnourished groups, and this finding can be clarified by the essential role of diet in sustaining an effective host defense. Overgrowth was found in underfed Kids in Africa of periodontopathic species and leaves. Due to the development of extracellular glucans, excessive consumption of sucrose is related to elevated plaque content, and there is a significant correlation between plaque density and gingivitis. In contrast to lower sucrose intakes, clinical intervention trials have reported greater plaque levels and elevated gingivitis with high glucose diets. Moynihan and Petersen, however, found out that 'the maximal decrease of dietary sugar beyond the boundaries of practicability is not able to prevent gingivitis from progressing [53].

Sharma et al. stated that the adjunctive utilization of an EO-containing mouth rinse offers a therapeutically important and relevant additional potential to lower plaque accumulation for patient populations with gingivitis who brush and floss regularly [54]. Pulikottil and Nath focused on a review of contemporary science and technical literature on the characteristics of cloves to investigate the possibilities for its use in the management of plaqueinduced periodontal diseases. It was concluded that cloves have antibacterial, general anesthesia, and analgesic characteristics bactericidal, antioxidant, anti-viral, anti-mycotic, anti-carcinogenic. Clove oil has a particular anti-inflammatory potential since it blocks the enzyme cyclo-oxygenase-2 and lipo-oxygenase [55]. Pramod et al. concluded that various ancient medicinal herbs exist to care for and mitigate teeth, gums, and oral hygiene-related diseases. Through the use of clove oil for periodontium disorders is an old treatment now practiced. The goal is to provide an overall view of the latest methods implemented to devise and apply conventional herbal remedies [56]. Gursoya et al. analyzed the inhibitory and antibiofilm bacterial growth effects of Saturejahortensis L (summer savory), Salvia fruticosa M(sage), Lavandula stoechas L. (lavender), essential oils, Myrtus communis L., and Juniperus communis (juniper). The present study demonstrated that Shortensis essential oil prevents the proliferation of microorganisms at keratinocyte-safe concentrations but that its anti-biofilm effect is reduced at sub-inhibitory concentrations [57]. Applications of essential oils in the management of periodontal diseases are in Table 3.

\subsection{Gingivitis and plaque.}

There are several gingival disorders threatening children which can develop to endanger the human periodontium. The symptoms of periodontal disorders occurring in adults typically originate earlier in life. Tooth eruption-associated gingivitis is abundant. The tooth explosion, though, does not induce gingivitis. It can be triggered by an elevated risk of plaque build-up in areas of principal teeth losing and permanent teeth emanating, as it can be impossible or even painful to practice oral hygiene. The inflammation modifications magnify the gingival margin's usual prominence and produce the appearance of a pronounced gingival broadening. 
Table 3. Applications of essential oils in the management of periodontal diseases.

\begin{tabular}{l|l|l|c} 
S. & Title & Interpretation & References \\
\hline 1 & $\begin{array}{l}\text { Potential of Clove of } \\
\text { Syzygiumaromaticum } \\
\text { development of a therapeutic agent } \\
\text { for periodontal disease: A review }\end{array}$ & $\begin{array}{l}\text { There is a distinct possibility for utilization of Clove as well } \\
\text { is its components as effective and anti-inflammatory } \\
\text { therapies of periodontal disease. Additional researches must } \\
\text { focus on the production of novel clove-based medicines } \\
\text { within the category of a localized drug carrier or topical agent } \\
\text { for the prevention of chronic periodontitis. }\end{array}$ & [55] \\
\hline 2 & $\begin{array}{l}\text { Anti-biofilm properties of Satureja } \\
\text { hortensis L. essential oil against } \\
\text { periodontal pathogens }\end{array}$ & $\begin{array}{l}\text { The latest results indicate that S. hortensis L. The essential oil } \\
\text { prevents the development of periodontium pathogens at } \\
\text { keratinocyte-safe concentrations, but its anti-biofilm activity } \\
\text { is reduced at sublethal doses. }\end{array}$ & [57] \\
\hline 3 & $\begin{array}{l}\text { Herbs as an antioxidant arsenal for } \\
\text { periodontal diseases }\end{array}$ & $\begin{array}{l}\text { Findings have demonstrated a strong link amongst elevated } \\
\text { tissue disruption biomarker ratios causing oxidative (ROS) } \\
\text { and periodontitis severity. Therefore, owing to its wide } \\
\text { ariety of biological and therapeutic practices, lower prices, } \\
\text { and particular asset margin, the focal point has stemmed back } \\
\text { to herbal remedies. }\end{array}$ & [58] \\
\hline 4 & $\begin{array}{l}\text { Lemongrass essential oil gel as a } \\
\text { local drug delivery agent for the } \\
\text { treatment of periodontitis }\end{array}$ & $\begin{array}{l}\text { Phytoscience study has discovered a modern alternative of } \\
\text { optional antimicrobial therapy provided by different } \\
\text { medicinal plants. Stapf, Cymbopogon citratus. A traditional } \\
\text { medicine plant is (lemongrass). Lemongrass natural oil } \\
\text { prevents the production of many forms of microbes, namely } \\
\text { periodontal bacteria, at a concentration of about 2 percent. }\end{array}$ & [59]
\end{tabular}

The plaque is a tenaciously intact coating on the teeth. The matrix is primarily microbial, composed of polysaccharides and collagen, but part of it is taken out from saliva. The plaque is colorless and forms on the tooth's strong and uneven surfaces. In these various locations, plaque may be supra or subgingival and varies in structure and in its performance. Plaque is implicated with either the origin of dental caries or periodontal disease, but variables that influence the impact of a plaque on specimens are the existence of the microbial community and, to some degree, the location.

Marco Antonio Botelho concluded antibacterial activities toward pathogenic bacteria, and for gingivitis decline, several diverse species extracts were assessed. The goal of this work was to evaluate the brief effectiveness and safety of mouth rinse essential oil based on Lippiasidoides ('alecrimpimenta') on gingival bleeding and bacterial plaque. Especially in comparison to the mean, the findings revealed reduced plaque level, gingival level, and gingival bleed index ratings at seven days. There were slight and transient risk factors. The study results indicated that mouth rinse, relying on L.sidoides, was reliable and safe in lowering plaque and gingival inflammation [60].

Baurothd concluded that dental floss is also found to be effective in gingivitis and plaque control. Rinsing two times every day with an essential oil mouthwash has been equally as effective as flossing regularly in minimizing interproximal plaque accumulation in tandem with clinical treatment (prophylaxis) and dental cleanings for 6 months [61]. Kothiwale et al., reported anti-plaque and antigingivitis tools, the freshly developed natural mouth rinse containing various essential oils like tea tree oil, Clove oil, etc., and are widely viable mouth rinse are scientifically helpful. A substantial decrease in microbiota CFU at three weeks was demonstrated by freshly formulated mouth rinses. Our results also endorse the routine usage for greater effectiveness of herbal mouthwashes as both an anti-plaque, antigingivitis, and antibacterial rinse [62]. Allakera and Ian Douglas proposed the study to compare the entire situation concerning innovative therapies. Oral care management also requires the use of synthetic chemicals. Upwards of 25percent of a total of pharmaceutical and over-the-counter formulations are derived from plants, and the ability of biological substances for oral 
maintenance therapy will thus be recognized. Targeted therapies can be aimed at periodontitisassociated black-pigmented anaerobic bacteria. Selective destruction of Porphyromonasgingivalis and Prevotella intermedia in biofilms has been seen in studies to date. For the treatment of periodontal diseases, functional reduction techniques involving protease antagonists have also been studied. Rajiv M Patel \& Zainab Malaki described essential oils' effect on plaque and gingivitis in mouthwash. Despite the assessment index used, there has been a substantial decrease in gingivitis for EO mouth rinses relative to test groups [63]. Uses of essential oils in gingivitis and plaque in Table 4.

\subsection{Dental pain.}

Dental discomfort is accompanied by the stimulus of intense noxious pain, such as microbial infection chemicals or mechanical enamel erosion and gingiva depletion. The first system in dentinal sensation signal transduction, post-dental insult, is patent dentinal tubules. Fluid displacement inside the tooth structure causes damage by pain fibers situated across the odontoblast cycle and at the pulp dentine boundary, however, according to hydrodynamic theory. In pain delivery, a dense matrix of trigeminal sensory axons strongly linked to odontoblasts can also be concerned [64]. Uses of essential oils in dental pain in Table 5.

Table 4. Uses of essential oils in gingivitis and plaque.

\begin{tabular}{l|l|l|c|} 
S. No. & Title & Interpretation & References \\
\hline 1 & $\begin{array}{l}\text { Comparative effect of an essential oil } \\
\text { mouth rinse on plaque, gingivitis, and } \\
\text { salivary Streptococcus mutans levels: a } \\
\text { double-blind, randomized study }\end{array}$ & $\begin{array}{l}\text { The findings show that Chlorhexidine mouth rinse decreased more } \\
\text { effectively the plaque level, gingival recession, and the amount of CFUs } \\
\text { (colony forming units) than L. Sidoides did not produce statistical power, } \\
\text { however. This research showed that in minimizing microbiota plaque \& } \\
\text { gingival inflammation, Lippiasidoides EO mouth rinse is successful. }\end{array}$ \\
\hline 2 & $\begin{array}{l}\text { The effect of a mouth rinse containing } \\
\text { essential oils on dental plaque and } \\
\text { gingivitis. Evidence-Based Dentistry }\end{array}$ & $\begin{array}{l}\text { Essential oils' effect was studied on plaque and gingivitis in mouthwash. } \\
\text { Despite the assessment index used, there has been a substantial decrease in } \\
\text { gingivitis for EO mouth rinses relative to test groups. }\end{array}$ \\
\hline 3 & $\begin{array}{l}\text { A comparative study of anti-plaque and } \\
\text { antigingivitis effects of an herbal mouth } \\
\text { rinse containing tea tree oil, Clove, and } \\
\text { basil with commercially available } \\
\text { essential oil mouth rinse }\end{array}$ & $\begin{array}{l}\text { As anti-plaque as well as antigingivitis agents, the freshly developed } \\
\text { natural mouth rinse and a widely viable mouth rinse are scientifically } \\
\text { helpful. A substantial decrease in bacterial at 21 days was demonstrated by } \\
\text { freshly developed mouth rinses. Our results also endorse the routine usage } \\
\text { for greater effectiveness of herbal mouthwashes as either an anti-plaque, } \\
\text { antigingivitis, or antimicrobial drain. }\end{array}$ \\
\hline 4 & $\begin{array}{l}\text { The adjunctive benefit of an essential } \\
\text { oil-containing mouth rinse reduces } \\
\text { plaque and gingivitis in patients who } \\
\text { brush and floss regularly. }\end{array}$ & $\begin{array}{l}\text { The mouthwash formulation has essential oils found to be significantly } \\
\text { effective against gingivitis as well as plaque. }\end{array}$ \\
\hline [64]
\end{tabular}

Table 5. Uses of essential oils in dental pain.

\begin{tabular}{l|l} 
S.No. & Title \\
\hline 1 & $\begin{array}{l}\text { Analgesic-Like Activity of Essential } \\
\text { Oil Constituents: An Update }\end{array}$ \\
\hline 2 & $\begin{array}{l}\text { Therapeutic uses of Ocimum } \\
\text { Sanctum linn (tulsi) with a note of } \\
\text { Eugenol and its pharmacological } \\
\text { actions: A SHORT REVIEW }\end{array}$ \\
\hline 3 & $\begin{array}{l}\text { Evaluation of lavender oil as a topical } \\
\text { analgesic agent before dental } \\
\text { anesthesia through pain rating scales } \\
- \text { An in vivo study }\end{array}$ \\
\hline
\end{tabular}

Interpretation

References

Therapeutic trials show the medicinal ability for the prevention and successful application of various disorders as analgesic-like chemicals. This research relies on recent research of the active compounds of essential oils, including analgesiclike efficacy, including a summary of their modes of action and chemical implications, recognizing that pain impacts a large portion of the worldwide inhabitants and, with that, the invention of novel analgesics.

A specific herb seen here in India, Ocimum sanctum Linn (known as Tulsi in Hindi), was being utilized to manage chest infections, dysentery, skin infections, asthma, severe eye infections, constant fever, insect bites, etc. The Sanctum Ocimum L. The possession of antimicrobial, antibacterial, cardioprotective, analgesic was further reported.

During local penetration anesthesia, lavender oil demonstrated greater effectiveness than benzocaine gel in reducing pain tolerance. It could be efficiently seen as a supplement for finding significant correlation analgesia with biologically derived general anesthesia. 
Table 6. Recent literature update on the use of essential oil for dental diseases.

\begin{tabular}{|c|c|c|c|}
\hline S.No. & Oil/source & Description & References \\
\hline 1. & $\begin{array}{l}\text { Clove, Cinnamon, and Thyme } \\
\text { Eugenia caryophyllata, Cinnamomum } \\
\text { verum, and Thymus vulgaris }\end{array}$ & $\begin{array}{l}\text { Due to its antimicrobial activities against many bacterial } \\
\text { species in the mouth, it is widely used in medicine as an } \\
\text { antiseptic against infectious illnesses such as infectious } \\
\text { periodontal pathologies. }\end{array}$ & [68] \\
\hline 2. & $\begin{array}{l}\text { Mexican mint oil, eugenol, and terpinen- } \\
\text { 4-ol } \\
\text { Coleus amboinicus, Syzygium } \\
\text { aromaticum }\end{array}$ & $\begin{array}{l}\text { demonstrated excellent antibacterial properties and } \\
\text { sensory qualities }\end{array}$ & [69] \\
\hline 3. & $\begin{array}{l}\text { Manuka oil and Tea tree oil } \\
\text { Leptospermum } \\
\text { scoparium and Melaleuca } \\
\text { alternifolia }\end{array}$ & showed strong antibacterial action against P.gingivalis & {$[70]$} \\
\hline 4. & $\begin{array}{l}\text { Thyme oil and Black sesame } \\
\text { Thymus vulgaris and } \\
\text { Hyptisspicigera }\end{array}$ & $\begin{array}{l}\text { The essential oil inhibited cariogenic species and } \\
\text { decreased bacterial adhesion to dental enamel. }\end{array}$ & [71] \\
\hline 5. & $\begin{array}{l}\text { oregano, thyme, and cinnamon } \\
\text { Origanum vulgare, Thymus vulgaris, and } \\
\text { Cinnamomum verum }\end{array}$ & $\begin{array}{l}\text { added to fluoride-free toothpaste to boost inhibitory } \\
\text { effects against bacteria linked with cavities and } \\
\text { periodontal disease; also improves the efficacy of } \\
\text { chlorhexidine-containing dentifrices }\end{array}$ & {$[72]$} \\
\hline 6. & $\begin{array}{l}\text { Mentha spp. } \\
\text { Mentha piperita } \\
\text { (M.spicata L.,M. xpiperita L. and } \\
\text { M.pulegium L.) }\end{array}$ & $\begin{array}{l}\text { Mentha spp. essential oil is a promising agent for } \\
\text { maintaining and promoting healthcare due to its } \\
\text { antimicrobial qualities and ability to function as an } \\
\text { antibacterial agent against caries. }\end{array}$ & [73] \\
\hline 7. & $\begin{array}{l}\text { Myrtle oil } \\
\text { Myrtus communis }\end{array}$ & $\begin{array}{l}\text { Myrtle oil has potent antimicrobial activity against a } \\
\text { variety of oral pathogens. }\end{array}$ & {$[74]$} \\
\hline 8. & $\begin{array}{l}\text { Lime } \\
\text { Citrus aurantifolia }\end{array}$ & $\begin{array}{l}\text { At a concentration of } 2 \% \text { essential oils, a mouth rinse } \\
\text { formulation based on essential oils of lime }(C \text {. } \\
\text { aurantifolia) peel begins to inhibit the growth of S. mutans } \\
\text { bacteria. }\end{array}$ & [75] \\
\hline 9. & $\begin{array}{l}\text { Thyme and oregano } \\
\text { Origanum vulgare and Thymus vulgaris }\end{array}$ & $\begin{array}{l}\text { Essential oils of thyme and oregano showed potential } \\
\text { antibacterial properties in both growth inhibition and cell } \\
\text { death in planktonic and biofilm stages. }\end{array}$ & {$[76]$} \\
\hline 10. & $\begin{array}{l}\text { Orange flower } \\
\text { Citrus aurantium } L \text {. }\end{array}$ & $\begin{array}{l}\text { The effects of this essential oil on human gingival } \\
\text { epithelial cell adhesion and growth were studied utilizing } \\
\text { cell adhesion and proliferation assays. }\end{array}$ & [77] \\
\hline
\end{tabular}

\section{Dental formulations}

\subsection{Toothpastes.}

These are popular oral care products whose chemical composition is constantly changing due to the producer's competition. Toothpaste is commonly regarded as the most powerful source of fluoride for preserving the deciduous and permanent teeth from caries [60]. Fluorides, on the other hand, aren't the only major components in toothpaste. Essential oils such as Clove, oregano, thyme, and cinnamon can be added to fluoride-free toothpaste to boost inhibitory effects against microorganisms linked to cavities and periodontal disease. Dentifrices containing chlorhexidine may benefit from the use of thyme essential oil [72]. A variety of substances with different properties to prevent the growth of microbes in the oral cavity, as well as a variety of ingredients with specific purposes to solve specific problems, are also essential in the cleaning abilities of toothpaste provided by abrasives, as well as the antibacterial abilities that are provided by the antibacterial abilities of toothpaste. On the other hand, Goerge et al. the herbal-based toothpaste was found to be just as effective as the normally formulated dentifrice in preventing plaque and gingivitis [78]. Bardellini et al. Bioxtra toothpaste has no impact on the quality of life of children undergoing chemotherapy, and it can be recommended as a clinically effective way to improve oral hygiene standards [79]. Ulusoyetal, the authors concluded that herbal toothpaste showed statistically strong antibacterial activity against Streptococcus mutans $(\mathrm{p}<0.05)$ than its initial type after incorporation of essential oils [80]. 


\subsection{Mouthwash.}

Oral rinse, mouth rinse is a liquid that is passively retained in the mouth, which can be gargled with the head hanging back and the liquid bubbling at the corner of the mouth, or it can be held in the mouth by contracting the perioral muscles and moving the head. Mouthwashes are antimicrobial solutions that are used to reduce the number of bacteria in the mouth. Contracting of the perioral muscles and movement of the head, or may be gargled with the head hanging back and the liquid bubbling at the corner of the mouth. Mouthwashes are usually antimicrobial solutions used to reduce the bacterial count in the oral cavity, but they can also be used for other purposes such as anti-fungal, anti-inflammatory, or analgesic properties. Alshehri, LISTERINE, an essential-oil-containing mouth rinse, has been shown to have anti-gingivitis and anti-plaque benefits when used with normal brushing teeth and interdental cleaning [81]. Neely came to the conclusion that $\mathrm{CHX}$ is still the first option when plaque prevention is the objective of care [82]. Myung-Haeng et al. an essential oil mixture of diluted tea tree, peppermint, and lemon, can be an efficient way to reduce malodor and VSC (volatile sulfur compounds) in intensive care units [83].

\subsection{Gels.}

Tooth gel is a smooth oral care substance with a high silica content that is often transparent or translucent in appearance [84]. To avoid tooth decay, Sodium Fluoride gel is used. It also assists in the reduction of tooth sensitivity, e.g., Fluorident, Dentagel, Neutracare. Santamaria et al. The natural oil of Melaleuca alternifolia, developed as a dental gel, is effective in controlling microbial biofilms after clinical declaration and categorization of Streptococcus mutans in the saliva of patients treated [21]. Soukoulis et al. Although further research is needed, the anti-inflammatory properties of TTO-containing gel applied topically to swollen gingival tissues may appear to be a useful non-toxic complement to chemotherapeutic periodontal therapy [88].

Table 7. Clinical study.

\begin{tabular}{l|l|l|c} 
S.No & Oil/ Source & Clinical study outcome & Reference \\
\hline 1. & $\begin{array}{l}\text { Lemongrass oil } \\
\text { Cymbopogon flexuosus }\end{array}$ & $\begin{array}{l}\text { Lemongrass oil was compared with that of chlorhexidine } \\
\text { mouthwash and showed better efficacy in gingivitis and plaque } \\
\text { reduction. }\end{array}$ & [86] \\
\hline 2. & $\begin{array}{l}\text { Orange flower } \\
\text { Citrus aurantium } \mathrm{L}\end{array}$ & $\begin{array}{l}\text { Bitter orange flower oil has shown a reduction in oral infections } \\
\text { as well as the S. mutans growth. }\end{array}$ & [77] \\
\hline 3. & $\begin{array}{l}\text { Pepper-rosmarin } \\
\text { Lippia sidoides }\end{array}$ & $\begin{array}{l}\text { The denture cleanser solution was tested and showed } \\
\text { antimicrobial activity, also, in the treatment of denture-induced } \\
\text { infections. }\end{array}$ & [87] \\
\hline 4. & $\begin{array}{l}\text { Oregano oil } \\
\text { Origanum vulgare }\end{array}$ & $\begin{array}{l}\text { Without the use of oregano oil, the findings indicate substantial } \\
\text { bacterium contamination in all plates. Oregano is a natural } \\
\text { antibiotic that could be as powerful as modern medication towards } \\
\text { pathogenic germs, particularly gram-positive and gram-negative } \\
\text { bacteria found in dental aerosols. }\end{array}$ & [88] \\
\hline 5. & $\begin{array}{l}\text { Cinnamon essential oil } \\
\text { Cinnamomum verum }\end{array}$ & $\begin{array}{l}\text { The antibacterial and antibiofilm effects of cinnamon essential oil } \\
\text { nanoemulsion }(\text { CEON) towards oral biofilms produced in a micro } \\
\text { biofilm model were investigated. The development of multi- } \\
\text { species oral biofilms and the proliferation of oral pathogens in } \\
\text { biofilms, particularly aciduric bacteria that cause tooth caries, } \\
\text { were both suppressed by nanoemulsified CEO, according to this } \\
\text { analysis. }\end{array}$ & [89] \\
\hline 6. & $\begin{array}{l}\text { The discoveries concerning C. Myrrha were discussed in this } \\
\text { review. It appears to have appropriate anti-inflammatory and } \\
\text { antibacterial actions in oral and dental tissues, according to } \\
\text { accumulating data. Still, the data is limited, and further research }\end{array}$ &
\end{tabular}




\begin{tabular}{l|l|l|c|}
\hline S.No & Oil/ Source & Clinical study outcome & Reference \\
\hline 7. & $\begin{array}{l}\text { Lippia } \\
\text { Lippia Thymoide }\end{array}$ & $\begin{array}{l}\text { Theeded to fully understand its antimicrobial properties on } \\
\text { various periodontal infections. }\end{array}$ & $\begin{array}{l}\text { Thymol, is tremendous potential towards gram-negative } \\
\text { periodontopathogenic microorganisms, which have a limited } \\
\text { treatment armament. }\end{array}$ \\
\hline 8. & $\begin{array}{l}\text { Ajwain } \\
\text { Trachypermum ammi }\end{array}$ & $\begin{array}{l}\text { From the study, it was found that For two months, the herbal } \\
\text { mouthwash remained steady, with no physical changes or } \\
\text { microbiological contamination } 0.05) \text { The anti-inflammatory } \\
\text { activity of T. ammi oil was equivalent to chlorhexidine, whereas } \\
\text { chlorhexidine decreased the probability of plaque index, bleeding } \\
\text { index, and modified gingival index more than the herbal } \\
\text { mouthwash. }\end{array}$ & [92] \\
\hline 9. & $\begin{array}{l}\text { Tea Tree Oil } \\
\text { Melaleuca alternifolia }\end{array}$ & $\begin{array}{l}\text { According to the findings, a mouth rinse containing TTO has a } \\
\text { significant influence on plaque and gingival grades as } \\
\text { Chlorhexidine. As a result, the TTO can be suggested as a mouth } \\
\text { rinse because it is a natural substance that is also inexpensive. }\end{array}$ & [93] \\
\hline 10. & $\begin{array}{l}\text { Chamomile } \\
\text { Matricaria chamomilla }\end{array}$ & $\begin{array}{l}\text { The findings show that chamomile essential oil can prevent } A . \\
\text { actinomycetemcomitans and } T \text {. denticola biofilms from forming. } \\
\text { As a result, it might be used as a therapeutic option to block the } \\
\text { biofilms formed by the bacteria studied in periodontal disease } \\
\text { patients. However, additional study is needed to understand the } \\
\text { processes behind this impactfully. }\end{array}$ & [94]
\end{tabular}

Table 8 represents some of the patents that are filed in context to the use of essential oils in dental care.

Table 8. Patents on essential oils and their formulations for the management of dental diseases.

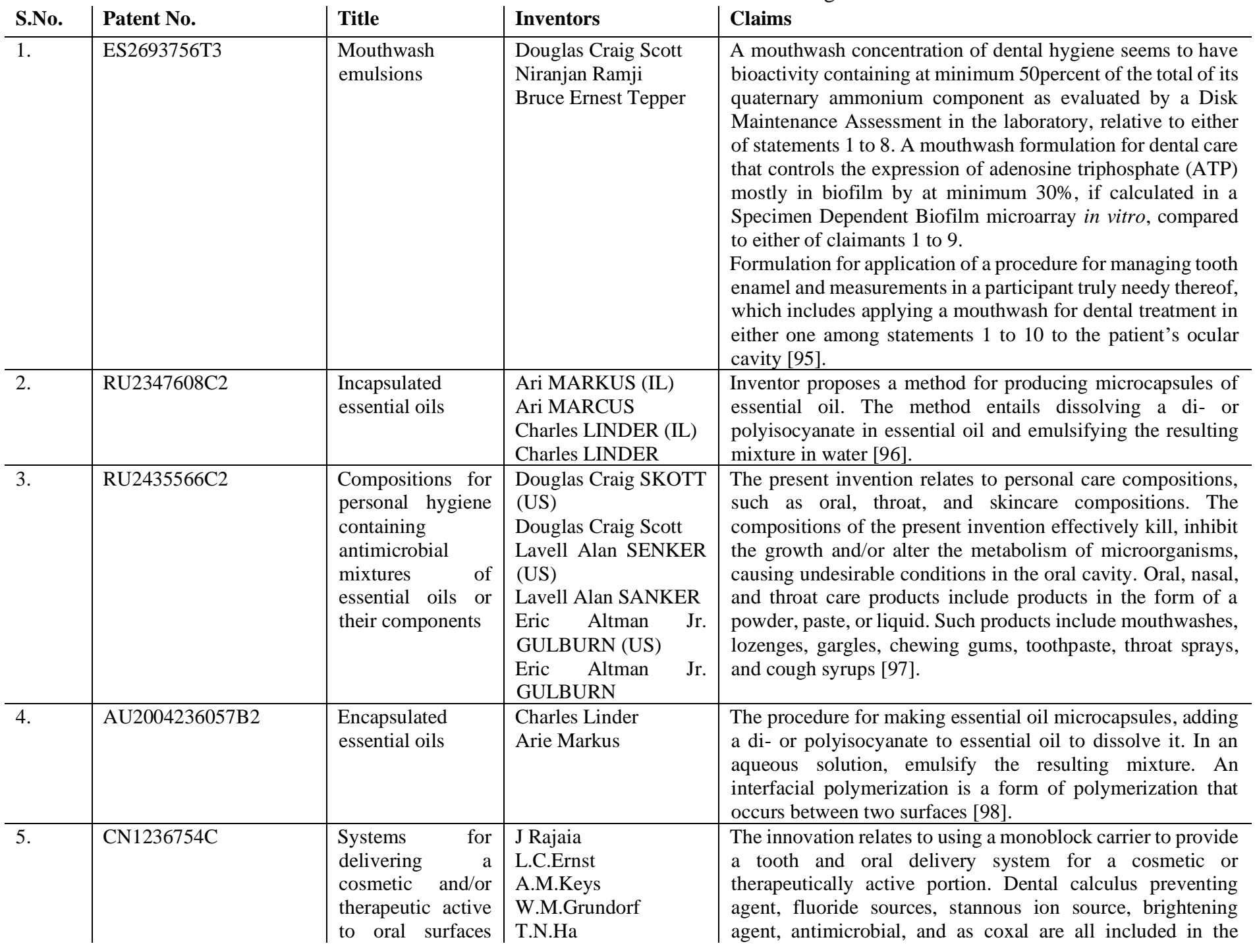




\begin{tabular}{|c|c|c|c|c|}
\hline S.No. & Patent No. & Title & Inventors & Claims \\
\hline 6. & ES2402786T5 & $\begin{array}{l}\text { Flavoring oils } \\
\text { with reduced } \\
\text { sulfur content for } \\
\text { use in oral care } \\
\text { compositions }\end{array}$ & $\begin{array}{l}\text { Steven Hamilton } \\
\text { HOKE II. } \\
\text { Marc Alan Hester } \\
\text { Niranjan Ramji }\end{array}$ & $\begin{array}{l}\text { Combining the flavoring oil with an aqueous phase that is } \\
\text { water or a mixture of water/solvent with a neutral pH, } \\
\text { subjecting the aqueous and oily phases to mixing conditions, } \\
\text { allowing the phases to be separated and the washed oil phase } \\
\text { to be collected, Where the precursor species selected from } \\
\text { dimethyl sulfoxide, dimethyl sulfide, dimethyl disulfide, and } \\
\text { dimethyl sulfone make up less than } 20 \text { parts per million (ppm) } \\
\text { by weight per volume of oil in the washed oil [100]. }\end{array}$ \\
\hline 7. & KR20100063124A & $\begin{array}{l}\text { Sustained release } \\
\text { dosage forms for } \\
\text { delivery of agents } \\
\text { to an oral cavity of } \\
\text { a user. }\end{array}$ & $\begin{array}{l}\text { Benjamin froth } \\
\text { Jerry B. Jean }\end{array}$ & $\begin{array}{l}\text { A slow-release lozenge containing a progressively dissolving } \\
\text { matrix containing a, whereby the matrix dissolves } \\
\text { significantly in an aqueous phase over a long period [101]. }\end{array}$ \\
\hline
\end{tabular}

\section{Conclusion}

Oral health plays a significant role in the overall well-being of humans. According to the latest WHO study, oral diseases are the most commonly existing diseases in society, which cause discomfort, pain, loss of teeth, and even death in a few cases. Dental diseases are classified as dental caries, periodontal diseases, gingivitis, plaque, dental pain. Essential oils obtained from Clove, lavender, cinnamon, eucalyptus, lemon, tea tree, ylang-ylang, coconut, spearmint has been reported to possess significant therapeutic efficacy in dental diseases. Essential oils are frequently used for the treatment of oral diseases because of their antimicrobial and anti-inflammatory properties.

\section{Funding}

This research received no external funding.

\section{Acknowledgments}

The authors thankfully acknowledge the support and facilities provided by Chitkara College of Pharmacy, Chitkara University, Punjab, India.

\section{Conflicts of Interest}

The authors declare no conflict of interest.

\section{References}

1. Fuentes, C.; Fuentes, A.; Barat, J.M.; Ruiz, M.J. Relevant essential oil components: a minireview on increasing applications and potential toxicity. Toxi Mech Meth 2021, 1-27, https://doi.org/10.1080/15376516.2021.1940408.

2. Palombo, E.A. Traditional medicinal plant extracts and natural products with activity against oral bacteria: Potential application in the prevention and treatment of oral diseases. Evid Based Complement Alternat Med 2011, 11, 1-15, https://doi.org/10.1093/ecam/nep067.

3. Mancianti, F.; Ebani, V.V. Biological activity of essential oils. Molecu 2020, 25, 678, https://doi.org/10.3390/molecules25030678.

4. Properzi, A.; Angelina, P.; Bertuzzi, G.; Venanzoni, R. Some biological activities of essential oils. Med Aromat Plants 2013, 2, 136, http://dx.doi.org/10.4172/2167-0412.1000136.

5. Petersen, P.E. The World Oral Health Report 2003: Continuous improvement of oral health in the 21st centurythe approach of the WHO Global Oral Health Programme. Community Dent Oral Epidemiol 2003, 31, 3-23. https://doi.org/10.1046/j.2003.com122.x. 
6. Aćimović, M. (2021). Essential Oils: Inhalation Aromatherapy-A Comprehensive Review. J of Agronomy Techno and Engineer Manag, 2021, 4, 547-557.

7. Fortune business insight "Essential oil market size, growth and share" accessed March 19, 2021(https://www.fortunebusinessinsights.com/industry-reports/essential-oils-market-101063).

8. Müller, W.E.; Sillani, G.; Schuwald, A.; Friedland, K. Pharmacological basis of the anxiolytic and antidepressant properties of Silexan ${ }^{\circledR}$, an essential oil from the flowers of lavender. Neurochem Intern 2021, 143, 104899, https://doi.org/10.1016/j.neuint.2020.104899.

9. Hunsrisakhun, J.; Talungchit, S.; Naorungroj, S. Effectiveness of alcohol-free mouth rinse containing essential oils and fluoride as an oral hygiene adjunct among pregnant Thai women: A randomized clinical trial. $J$ Internat Soci Preven Commu Dent 2020, 10, 803, https://dx.doi.org/10.4103\%2Fjispcd.JISPCD_289_20.

10. Pizzo, G.; La Cara, M.; Licata, M.E.; Pizzo, I.; D'Angelo, M. The effects of an essential oil and an amine fluoride/stannous fluoride mouthrinse on supragingival plaque regrowth. J Periodontol 2008, 79, 1177-1183, https://doi.org/10.1902/jop.2008.070583.

11. Fine, D.H.; Markowitz, K.; Furgang, D.; Goldsmith, D.; Ricci-Nittel, D.; Charles, D.C. Effect of rinsing with an essential oil-containing mouthrinse on subgingival periodontopathogens. J Periodontol 2007, 78, 19351942. http://dx.doi.org/10.1902/jop.2007.070120.

12. Al-Radha, A.S.; Younes, C.; Diab, B.S.; Jenkinson, H.F. Essential oils and zirconia dental implant materials. Int J Oral Maxillofac Implants 2013, 28, 1497-505, https://doi.org/10.11607/jomi.3142.

13. Dawkins, E.; Michimi, A.; Ellis-Griffith, G.; Peterson, T.; Carter, D. Dental caries among children visiting a moble dental clinic in south central Kentucky: a pooled cross-sectional study. BMC Oral Health 2013, 13:19, https://doi.org/10.1186/1472-6831-13-19.

14. Herman, A.; Herman, A.P.; Domagalska, B.W.; Mlynarczyk, A. Essential oils and herbal extracts as antimicrobial agents in cosmetic emulsion. Indian J Microbiol 2013, 53, 232-237, http://dx.doi.org/10.1007/s12088-012-0329-0.

15. Chaieb, K.; Hajlaoui, H.; Zmantar, T.; Kahla-Nakbi, A.B.; Rouabhia, M.; Mahdouani, K. The chemical composition and biological activity of clove essential oil, Eugenia caryophyllata (Syzigiumaromaticum L. Myrtaceae): A short review. Phytother Res 2007, 21, 501-506, https://doi.org/10.1002/ptr.2124.

16. Bradley, B.F.; Brown, S.L.; Chu, S.; Lea, R.W. Effects of orally administered lavender essential oil on responses to anxiety-provoking $\mathrm{lm}$ clips. Hum Psychopharmacol 2009, 24, 319-30, https://doi.org/10.1002/hup.1016.

17. Ooi, L.S.; Li, Y.; Kam, S.L.; Wang, H.; Wong, E.Y.; Ooi, V.E. Antimicrobial activities of cinnamon oil and cinnamaldehyde from the Chinese medicinal herb Cinnamomum cassia Blume. Am J Chin Med 2006, 34,51122, https://doi.org/10.1142/s0192415x06004041.

18. Bachir, R.G.; Benali, M. Antibacterial activity of the essential oils from the leaves of Eucalyptus globulus against Escherichia coli and Staphylococcus aureus. Asian Pac J Trop Biomed 2012, 2, 739-742, https://dx.doi.org/10.1016\%2FS2221-1691(12)60220-2.

19. Serano, A.; Sinibaldi, V.P.; Andreola, F.; Zonfrillo, M.; Mercuri, L.; Federici, M. Stimulatory effect of Eucalyptus essential oil on innate cell-mediated immune response. BMC Immunol 2008, 9, 17, https://doi.org/10.1186/1471-2172-9-17.

20. Bialon, M.; Krzysko-Lupicka, T.; Koszalkowska, M.; Wieczorek, P.P. The influence of chemical composition of commercial lemon essential oils on the growth of Candida strains. Mycopathologia 2014, 177, 29-39, https://doi.org/10.1007/s11046-013-9723-3.

21. Santamaria, M.; Petermann, K.D.; Vedovello, S.A.; Degan, V.; Lucato, A.; Franzini, C.M. Antimicrobial effect of Melaleuca alternifolia dental gel in orthodontic patients. Am J Orthod Dentofacial Orthop 2014, 145, 198-202, https://doi.org/10.1016/j.ajodo.2013.10.015.

22. Stashenko, E.; Martinez, J.R.; MacKu, C.; Shibamoto, T. HRGC and GC-MS analysis of essential oil from Colombian ylang-ylang (Cananga odorata Hook fil. Et Thomson, forma genuina). J of High Resolu Chromatogr 1993, 16, 441-444, https://doi.org/10.1002/jhrc.1240160713.

23. Peedikayil, F.C.; Sreenivasan, P.; Narayanan, A. Effect of coconut oil in plaque related gingivitis - a preliminary report. Niger Med J 2015, 56, 143-147, https://doi.org/10.4103/0300-1652.153406.

24. Kizil, S.; Hasimi, N.; Tolan, V.; Kilinç, E.; Yüksel, U. Mineral content, essential oil components and biological activity of two Mentha species (M. piperita L., M. spicata L.) Turk. J Field Crops 2010, 15, 148-153.

25. Scannapeico, F.A.; Mylotte, J.M. Relationship between periodontal disease and bacterial pneumonia. $J$ of Periodontol 1996, 13, 118-29, https://doi.org/10.1902/jop.1996.67.10s.1114.

26. Yoneyama, T.; Yoshida, M.; Ohrui, T. Oral care reduces pneumonia in older patients in nursing homes. $J$ of the Am Geri Soci 2002, 50, 430-443, https://doi.org/10.1046/j.1532-5415.2002.50106.x.

27. Honnor, A.; Law, A. Mouth care in cancer nursing: using an audit to improve practice. British J of Nursing 2002, 11, 1087-96, https://doi.org/10.12968/bjon.2002.11.16.10550.

28. Marur, T.T.Y.; Demirci, S. Facial anatomy. Clinics in Dermato 2014, 32, 10, https://doi.org/10.1016/j.clindermatol.2013.05.022.

29. Yousem, D.M.; Chalian, A.A. Oral cavity and pharynx. Radiol Clin North Am 1998, 36, 967-81, https://doi.org/10.1016/s0033-8389(05)70071-3. 
30. Koussoulakou, D.S.; Margaritis, L.H.; Koussoulakos, S.L. A curriculum vitae of teeth: evolution, generation, regeneration. Int J Biol Sci 2009, 5, 226-243, https://doi.org/10.7150/ijbs.5.226.

31. Thesleff, I. The genetic basis of tooth development and dental defects. Am J Med Genet 2006, 140, 2530-5, https://doi.org/10.1002/ajmg.a.31360.

32. Denny, P.C.; Ball, W.D.; Redman, R.S. Salivary glands: a paradigm for diversity of gland development. Crit Rev Oral Bio Med 1997, 8, 51-75, https://doi.org/10.1177/10454411970080010301.

33. Holmberg, K.V.; Hoffman, M.P. Anatomy, biogenesis and regeneration of salivary glands. Monogr Oral Sci 2014, 24, 1-13, https://doi.org/10.1159/000358776.

34. Lydiatt, D.D.; Bucher, G.S. The historical evolution of the understanding of the submandibular and sublingual salivary glands. Clin Anat 2012, 25, 2-11.

35. Miletich, I. Introduction to salivary glands: structure, function and embryonic development. Front Oral Biol 2010, 14, 1-20, https://doi.org/10.1159/000313703.

36. van der Bilt, A.; Engelen, L.; Pereira, L.J.; van der Glas, H.W.; Abbink, J.H. Oral physiology and mastication. Physiol Behav 2006, 89, 22-7, https://doi.org/10.1016/j.physbeh.2006.01.025.

37. Le Reverend, B.J.; Edelson, L.R.; Loret, C. Anatomical, functional, physiological and behavioural aspects of the development of mastication in early childhood. Br J Nutr 2014, 111, 403-414, https://doi.org/10.1017/s0007114513002699.

38. Khan, A.A.; Jain, S.K.; Shrivastav, A. Prevalence of dental caries among the population of Gwalior (India) in relation of different associated factors. Eur J Dent 2008, 2, 81-5.

39. Bali, R.K.; Mathur, V.B.; Talwar, P.P.; Chanana, H.B. Dental Council of India. New Delhi: National Oral health Survey and fluoride mapping 2004, 1-176.

40. Marcenes, W.; Kassebaum, N.J.; Bernabé, E.; Flaxman, A.; Naghavi, M.; Lopez, A. Global burden of oral conditions in 1990-2010: A systematic analysis. $J$ Dent Res 2013, 92, 592-7, https://doi.org/10.1177/0022034513490168.

41. Muhammad, S.; Lawal, M.T. Oral hygiene and the use of plants. Department of Scientific Research and Essays 2010, 5, 1788-1795, https://doi.org/10.5897/SRE.9000699.

42. Harley, J.P.; Soder, B.; Skaug, N. Microbiology, Fifth Edition, McGram Hill Higher Educ 2002, 39, 933-936.

43. Okoye, L.O.; Ekwueme, O.C. Prevalence of Dental Caries in a Nigerian Rural Community: A Preliminary Local Survey. Ann Med Health Sci Res 2011, 1, 187-196.

44. Franco, F.E.; Amoroso, P.; Marin, J.M.; Ávila, F.A. Detection of Streptococcus mutans and Streptococcus sobrinus in dental plaque samples from Brazilian preschool children by Polymerase Chain Reaction. Braz Dent J 2007, 18, 329-333, https://doi.org/10.1590/s0103-64402007000400011.

45. Moses, J.; Rangeeth, B.N.; Gurunathan, D. Prevalence of dental caries, socioeconomic old school going children of chidambaram status and treatment needs among 5 to 15 year old school going children of Chidambaram. J Clin Dign Res 2011, 5, 146-151.

46. Selwitz, R.H.; Ismail, A.I.; Pitts, N.B. Dental caries Lancet 2007, 369, 51-59, https://doi.org/10.1016/s01406736(07)60031-2.

47. Featherstone, J.D. The caries balance: the basis for caries management by risk assessment. Oral Health Prev Dent 2004, 2, 259-264.

48. Kouidhi, B.; Zmantar, T.; Bakhrouf, A. Anticariogenic and cytotoxic activity of clove essential oil (Eugenia caryophyllata) against a large number of oral pathogens. Ann Microbio 2010, 60, 599-604, https://doi.org/10.1007/s13213-010-0092-6.

49. Anand, T.D.; Pothiraj, C.; Gopinath, R.M.; Kayalvizhi, B. Effect of oil-pulling on dental caries causing bacteria. African J of Microbio 2008, 2, 063-066, https://doi.org/10.5897/AJMR.9000257.

50. Aneja, K.R.; Joshi, R.; Sharma, C. Antimicrobial activity of Dalchini (Cinnamomum zeylanicum bark) extracts on some dental caries pathogens. J Pharma Res 2009, 2, 1387-1390.

51. Moghadam, P.; Dadelahi, S.; Hajizadeh, Y.S.; Matin, M.G.; Amini, M.; Hajazimian, S. Chemical Composition and Antibacterial Activities of Sumac Fruit (Rhus coriaria) Essential Oil on Dental Caries Pathogens. The Open Microbio J 2020, 14, 142-146, http://dx.doi.org/10.2174/1874285802014010142.

52. Shetty, S.; Mahin-Syed-Ismail, P.; Varghese, S.; Thomas-George, B.; Kandathil- Thajuraj, P.; Baby, D.; Devang-Divakar, D. Antimicrobial effects of Citrus sinensis peel extracts against dental caries bacteria: An in vitro study. J Clin Exp Dent 2016, 8, 70-7, https://doi.org/10.4317/jced.52493.

53. Moynihan, P.; Petersen, P.E. Diet, nutrition and the prevention of dental diseases. Public Health Nutrition 2004, 7, 201-226, https://doi.org/10.1079/phn2003589.

54. Sharma, N.; Charles, C.H.; Lynch, M.C.; Qaqish, J.; McGuire, J.A.; Galustians, J.G.; Kumar, L.D. Adjunctive benefit of an essential oil-containing mouthrinse in reducing plaque and gingivitis in patients who brush and floss regularly: a six-month study. $J$ Am Dent Assoc 2004, 135, 496-504, https://doi.org/10.14219/jada.archive.2004.0217.

55. Pulikottil, S.J.; Nath, S. Potential of Clove of Syzygiumaromaticum in development of a therapeutic agent for periodontal disease: A review. S Afr dent J 2015, 70, 108-115.

56. Pramod, K.; Ansari, S.; Javed, A. Herbal Remedies for the Treatment of Periodontal Disease - A Patent Review. Recent Patents on Drug Deliv Formul 2009, 3, 221-228, https://doi.org/10.2174/187221109789105603. 
57. Gursoy, U.K.; Gursoy, M.; Gursoy, O.V.; Cakmakci, L.; EijaKönönen, Uitto, V. Anti-biofilm properties of Satureja hortensis L. essential oil against periodontal pathogens. Anaerobe 2009, 15, 164-167, https://doi.org/10.1016/j.anaerobe.2009.02.004.

58. Ramesh, A.; Varghese, S.S.; Doraiswamy, J.N.; Malaiappan, S. Herbs as an antioxidant arsenal for periodontal diseases. J of Intercultural Ethnopharmacol 2016, 5, 92, https://doi.org/10.5455/jice.20160122065556.

59. Scannapieco, F.A.; Gershovich, E. The prevention of periodontal disease-An overview. Periodont 2000 2020 84, 9-13, https://doi.org/10.1111/prd.12330.

60. Botelho, M.A.; Santos, R.A.; Martins, J.G.; Carvalho, C.O.; Paz, M.C.; Azenha, C.; Ruela, R.S.; Queiroz, D.B.; Ruela, W.S.; Marinho, G.; Ruela, F.I. Comparative effect of an essential oil mouthrinse on plaque, gingivitis and salivary Streptococcus mutans levels: a double blind randomized study. Phytotherapy Research: An Int J Pharmacol and Toxicol Evalu of Nat Pro Deriva 2009, 23, 1214-9, https://doi.org/10.1002/ptr.2489.

61. Baurothd, K.; Charles, C.H.; Mankodid, S.M.; Simmons, K.; Zhao, Q.; Kumar, L.D. The efficacy of an essential oil antiseptic mouthrinse vs. dental floss in controlling interproximal gingivitis: A comparative study. J Dent Assoc 2003, 134, 359-366, https://doi.org/10.14219/jada.archive.2003.0167.

62. Kothiwale, S.V.; Patwardhan, V.; Gandhi, M.; Sohoni, R.; Kumar, A. A comparative study of anti-plaque and antigingivitis effects of herbal mouthrinse containing tea tree oil, Clove, and basil with commercially available essential oil mouthrinse. J Indian Soc Periodontol 2014, 18, 316-20, https://doi.org/10.4103/0972124x.134568.

63. Patel, R.M.; Zainab, M. The effect of a mouthrinse containing essential oils on dental plaque and gingivitis. Evidence-Based Dentistry 2008, 9, 18-19, https://doi.org/10.1038/sj.ebd.6400566.

64. Kumarswamy. Multimodal management of dental pain with focus on alternative medicine:A novel herbal dental gel. Contemp Clini Dent 2016, 7, 131-139.

65. de Cássia da Silveira e Sá, Rita, Lima, Tamires, da Nóbrega, Flávio, de Brito, Anna, de zousa Damião. Analgesic-Like Activity of Essential Oil Constituents: An Update. Int J of Molecular Sciences 2017, 18, 2392, https://doi.org/10.3390/ijms18122392.

66. Parkash, P.; Gupta, N. Therapeutic uses of ocimum sanctum linn( tulsi) with a note of Eugenol and its pharmacological actions: A SHORT REVIEW. Indian J of Physiol Pharmacol 2005, 49, 125-31.

67. Pathan, J.M.; Dadpe, M.V., Kale, Y.J.; Dahake, P.T.; Kendre, S.B. Evaluation of lavender oil as a topical analgesic agent before dental anaesthesia through pain rating scales - An in vivo study. IOSR $J$ of Dent and Med Sci 2020, 19, 06-13, http://dx.doi.org/10.9790/0853-1907120613.

68. AL-Mahdi, Z. K. A.; Witwit, L. J.; Ubaid, I. A. Activity of Cloves, Cinnamon and Thyme Essential Oils Against Some Oral Bacteria. Al-Kitab J for Pure Sci 2021, 5, 2617-1260, https://doi.org/10.32441/kjps.05.01.p2.

69. Do, D.N.; Nguyen, D.P.; Tran, T.T.A.; Nguyen, D.Q.; Lai, N.M.T.; Huynh, T.H.; Do, V.M.; Luu, X.C.; Le, X.T. "Evaluation of antibacterial properties of some essential oils from Vietnam." In IOP Conf Ser: Mater Sci Eng 2021, 1166, 1, 012040, doi:10.1088/1757-899X/1166/1/012040.

70. Vaidya Jasmine, M.D.S.; Ravishankar, P.L.; Visithiriyan, G.; Preethikaa, G. An In-Vitro Evaluation of the Efficacy of the Essential Oils from Leptospermum Scoparium and Melaleuca Alternifolia as an Antimicrobial Agent against P. Gingivalis. Ann Roman Soci Cell Bio 2021, 25, 10291-10296.

71. de Oliveira, M.A.; da C Vegian, M.R.; Brighenti, F.L.; Salvador, M.J.; Koga-Ito, C.Y. Antibiofilm effects of Thymus vulgaris and Hyptis spicigera essential oils on cariogenic bacteria. Fut Microbio 2021, 16, 241-255, https://doi.org/10.2217/fmb-2020-0181.

72. de Oliveira Carvalho, I.; Purgato, G.A.; Píccolo, M.S.; Pizziolo, V.R.; Coelho, R.R.; Diaz-Muñoz, G.; Diaz, M.A.N. In vitro anticariogenic and antibiofilm activities of toothpastes formulated with essential oils. Arch Oral Bio 2020, 117, 104834, https://doi.org/10.1016/j.archoralbio.2020.104834.

73. Mostafa, D.A.; Bayoumi, F.S.; Taher, H.M.; Abdelmonem, B.H.; Eissa, T.F. Antimicrobial potential of Mentha Spp. essential oils as raw and loaded solid lipid nanoparticles against dental caries. Res J Pharm Tech 2020, 13, 4415-4422, http://dx.doi.org/10.5958/0974-360X.2020.00781.7.

74. Dobler, D.; Runkel, F.; Schmidts, T. Effect of essential oils on oral halitosis treatment: a review. Eur J Oral Sci 2020, 128, 476-486, https://doi.org/10.1111/eos.12745.

75. Mulyanti, S.; Laela, D.S.; Julaeha, E.; Suwargiani, A.A.; Aripin, D. Formulation of mouth rinse from the essential oils of lime (Citrus aurantifolia) and its inhibitory efficacy on the growth of Streptococcus mutansin vitro. Pad J Dent 2020, 32, 39-47, https://doi.org/10.24198/pjd.vol32no1.25486.

76. Aires, A.; Barreto, A.S; Semedo-Lemsaddek, T. Antimicrobial Effects of Essential Oils on Oral Microbiota Biofilms: The Toothbrush In Vitro Model. Antibio 2021, 10, 21, https://doi.org/10.3390/antibiotics10010021.

77. Benzaid, C.; Belmadani, A.; Tichati, L.; Djeribi, R.; Rouabhia, M. Effect of Citrus aurantium L. Essential Oil on Streptococcus mutans Growth, Biofilm Formation and Virulent Genes Expression. Antibio 2021, 10, 54, https://doi.org/10.3390/antibiotics10010054.

78. George J, Hegde S, Rajesh KS, Kumar A. The efficacy of a herbal-based toothpaste in the control of plaque and gingivitis: A clinico-biochemical study. Indian J Dent Res 2009;20(4):480-482.

79. Bardellini, E.; Amadori, F.; Majorana, A. Oral hygiene grade and quality of life in children with chemotherapyrelated oral mucositis: a randomized study on the impact of a fluoride toothpaste with salivary enzymes, 
essential oils, proteins and colostrum extract versus a fluoride toothpaste. Int J Dent Hyg 2016, 14, 314-319, https://doi.org/10.1111/idh.12226.

80. Karadağlığlu, Ö.İ.; Ulusoy, N.; Başer, K.H.C.; Hanoğlu, A.; Şık, İ. Antibacterial activities of herbal toothpastes combined with essential oils against streptococcus mutans. Pathogensis 2019, 8, 361-368. https://doi.org/10.3390/pathogens8010020.

81. Alshehri, F.A. The use of mouthwash containing essential oils (LISTERINE®) to improve oral health: A systematic review. Saudi Dent J 2018, 30, 2-6, https://doi.org/10.1016/j.sdentj.2017.12.004.

82. Neely, A.L. Essential oil mouthwash (EOMW) may be equivalent to chlorhexidine (CHX) for long-term control of gingival inflammation but CHX appears to perform better than EOMW in plaque control. $J$ Evid Based Dent Pract 2012, 12, 69-72, https://doi.org/10.1016/s1532-3382(12)70017-9.

83. Hur, M.H.; Park, J.; Maddock-Jennings, W.; Kim, D.O.; Lee, M.S. Reduction of Mouth Malodour and Volatile Sulphur Compounds in Intensive Care Patients using an Essential Oil Mouthwash. Phytother Res 2007, 21, 641- 643.

84. Alam, M. K.; Ganji, K.K. Nano-Bio Fusion Gingival Gel in the management of fixed orthodontic treatmentinduced gingivitis: An empirical study. Am J of Orthodo and Dentofac Orthope 2021, 159, 808-815, https://doi.org/10.1016/j.ajodo.2020.02.022.

85. Soukoulis, S.; Hirsch, R. The effects of a tea tree oil-containing gel on plaque and chronic gingivitis. Aust Dent J 2004, 49, 78-83, https://doi.org/10.1111/j.1834-7819.2004.tb00054.x.

86. Akula, S.; Nagarathna, J.; Srinath, S.K. Anti-Plaque and Anti-Gingivitis Efficacy of $0.25 \%$ Lemongrass Oil and $0.2 \%$ Chlorhexidine Mouthwash in Children. Front Dent 2021, 18, 32.

87. Barreto, J.O.; do Nascimento, F.B.S.A.; Fonseca, S.G.D.C.; Serpa Sampaio, L.; da Silva, C.R.; de Andrade Neto, J.B.; Júnior, H.V.N.; Regis, R.R. Microbiological evaluation of an experimental denture cleanser containing essential oil of Lippia sidoides. Biofou 2021, 37, 117-130, https://doi.org/10.1080/08927014.2021.1885649.

88. Sharmin, D.D.; Revathi, K.; Mahendra, J.; Anandhi, D.; Jasmine, S.S.M.A.J. Antibacterial efficacy of Oregano Oil (ORIGANUM VULGARE) on the type of bacteria and its count in Dental Aerosols. Ann Roman Soci Cell Bio 2021, 4140-4148.

89. Jeong, Y.J.; Kim, H.E.; Han, S.J.; Choi, J.S. Antibacterial and antibiofilm activities of cinnamon essential oil nanoemulsion against multi-species oral biofilms. Sci Rep 2021, 11, 1-8, https://doi.org/10.1038/s41598-02185375-3.

90. Adnan, A.A. Clinical Effects of Commiphora Myrrha in Oral and Dental Medicine, A Mini Review. On J Dent \& Oral Health 2021, 4, 1-2, http://dx.doi.org/10.33552/OJDOH.2021.04.000582.

91. Carvalho, T.R.B.; Tanaka, E.B.; Vilhena, A.T.; Frade, P.C.R.; de Souza Fonseca, R.R.; de Souza Rodrigues, T.M.; da Paz Brito, M.; Silva, S.G.; de Carvalho Junior, R.N.; de Oliveira, M.S.; de Aguiar Andrade, E.H. Chemical composition, antimicrobial and antifungal activity of Lippia Thymoide essential oil in oral pathogens. Braz J of Oral Sci 2021, 20, e210219-e210219, https://doi.org/10.20396/bjos.v20i00.8660219.

92. Saffarpour, A.; Amini, N.; Keshtkar, A.; Mokhber-Dezfuli, N. Comparative Effects of Mouthwash Containing Trachypermum ammi Oil with Chlorhexidine on Dental Plaque Induced Gingivitis. Res J Pharmaco 2020, 7 , 23-30, https://dx.doi.org/10.22127/rjp.2020.113428.

93. Divya, D.; Guruprasad, D.C.; Veera Reddy, D.; Darshana Bennadi, D.; Satish, G. Effectiveness of Tea Tree Oil and Chlorhexidine as Mouth Rinse in the Control of Dental Plaque and Chronic Gingivitis-A Comparative Study. Eur J Mole \& Clin Med 2020, 7, 1576-1582.

94. Nurrahman, H.F.; Widyarman, A.S. Effectiveness of Matricaria chamomilla essential oil on Aggregatibacter actinomycetemcomitans and Treponema denticola biofilms. J Indo Dent Assoc 2020,3, 77-82, https://doi.org/10.32793/jida.v3i2.563.

95. Scott, D.C.; Ramji, N.; Tepper, B.E. "Mouth emulsion" accessed February25,2021(https://patents.google.com/patent/ES2693756T3/es).

96. Markus, A.; Linder, C. "Incapsulated essential oils" accessed February25,2021

a. (https://patents.google.com/patent/RU2347608C2/en).

97. Skott, D.C.; Senker, L.A.; Gulburn, E.A. "Compositions for personal hygiene containing antimicrobial mixtures of essential oils or their components" accessed February25,2021(https://patents.google.com/patent/RU2435566C2/en).

98. Linder, C.; Markus, A. "Encapsulated essential oils" accessed February 25, 2021 (https://patents.google.com/patent/AU2004236057A1/en).

99. Rajaia, J.; Ernst, L.C.; Keys, A.M.; Grundorf, W.N.; Ha, T.N.; Meyer, C.R. "Systems for delivering a cosmetic and/or therapeutic active to oral surfaces using an integral carrier" accessed February25,2021(https://patents.google.com/patent/CN1236754C/en).

100.Hoke, H.S.; Hester, M.A.; Ramji, N. "Flavoring oils with reduced sulfur content for use in oral care compositions" accessed February 25, 2021 (https://patents.google.com/patent/ES2402786T5/en).

101.Froth, B.; Jean, J.B. "Sustained release dosage forms for delivery of agents to an oral cavity of a user" accessed February25,2021 (https://patents.google.com/patent/KR20100063124A/en). 